\title{
Tendensi dan komparasi Produk Domestik Regional Bruto dan Indeks Pembangunan Manusia Provinsi Kepulauan Bangka Belitung dan Kepulauan Riau
}

\author{
Sarpina ${ }^{1}$, Aning Kesuma Putri ${ }^{1}$, \& Hadi Suroso 2 \\ 1 Fakultas Ekonomi, Universitas Bangka Belitung, Indonesia \\ ${ }^{2}$ Badan Pusat Statistik Provinsi Kepulauan Bangka Belitung, Indonesia
}

\begin{abstract}
Abstrak Penelitian ini bertujuan untuk mengetahui tren dan perbandingan IPM dan PDRB di Provinsi Kepulauan Riau dan Bangka Belitung. Data yang digunakan dalam penelitian ini adalah data sekunder yang diperoleh dari berbagai sumber dan publikasi dari Badan Pusat Statistik Provinsi Kepulauan Riau and Bangka Belitung tahun 20142018. Analisis deskriptif kuantitatif untuk menjelaskan fenomena indeks pembangunan manusia dan PDRB di kedua provinsi tersebut. Temuan studi menemukan bahwa indeks pembangunan manusia dan produk domestik regional bruto mengalami peningkatan. Kondisi IPM di Provinsi Kepulauan Bangka Belitung dan Kepulauan Riau semakin membaik setiap tahunnya, dengan rata-rata IPM tertinggi selama periode 2014-2018. PDRB Kepualau Riau cenderung tumbuh lebih cepat dibanding Bangka Belitung. PDRB Provinsi Kepulauan Bangka Belitung dan Kepulauan Riau juga cenderung meningkat setiap tahun dengan rata-rata IPM selama periode 2014-2018. Kecenderungan pertumbuhan IPM Bangka Belitung lebih cepat dibandingkan di Kepulauan Riau.
\end{abstract}

Kata kunci: trend; perbandingan; deskriptif; PDRB; IPM

\begin{abstract}
This study aims to determine the trend and comparison of HDI and GRDP in the Provinces of Riau Islands and Bangka Belitung. The data used in this study are secondary data obtained from various sources and publications from the Central Bureau of Statistics, Bangka Belitung and Riau Islands Province 2014-2018. A quantitative descriptive analysis to explain the phenomenon of the human development index and GRDP in the two provinces. The findings of the study found that the human development index and gross regional domestic product have increased. The HDI conditions in the Province of Bangka Belitung Islands and Riau Islands are getting better every year, with the highest HDI average during the 2014-2O18 period. PDRB Kepualau Riau tends to grow faster than Bangka Belitung. The GRDP of the Bangka Belitung Islands and Riau Islands Provinces also tends to increase every year with an average HDI during the 2014-2018 period. The tendency of Bangka Belitung HDI growth is faster than in the Riau Islandscrisis is statistically significant to affect the gross regional domestic product growth.
\end{abstract}

Keywords: trend; comparison; descriptive; GRDP; HDI

JEL Classification: $O 1 O$; $O 15$; R1O 


\section{PENDAHULUAN}

Salah satu indikator untuk mengetahui kondisi suatu daerah dalam suatu periode tertentu adalah data Produk Domestik Regional Bruto (PDRB). PDRB sering dianggap sebagai indikator kesejahteraan ekonomi, meskipun sebenarnya ini adalah ukuran dari (beberapa) output perekonomian yang dikenal masyarakat (Aitken, 2019). Baik atas dasar harga berlaku maupun atas dasar harga konstan. Berdasarkan indikator ini kita akan memperoleh gambaran tingkat pertumbuhan ekonomi maupun tingkat memakmuran masyarakat suatu wilayah. Produk Domestik Bruto (PDB) merupakan salah satu indikator makro ekonomi yang pada umumnya digunakan untuk mengukur kinerja ekonomi di suatu negara. Sedangkan untuk tingkat wilayah, baik di tingkat wilayah provinsi maupun kabupaten atau kota digunakan Produk Domestik Regional Bruto (PDRB). PDRB merupakan bagian dari PDB, sehingga perubahan PDRB yang terjadi ditingkat regional akan berpengaruhi terhadap PDB atau sebaliknya (Syari dkk, 2017).

Pembahasan pembangunan tidak hanya tentang pertumbuhan pendapatan per kapita saja. Pembangunan merupakan suatu hal yang multidimensi yang mencakup berbagai aspek masyarakat seperti ekonomi, sosial, politik, hukum, dan keamanan. Pembangunan ekonomi sebagai proses peningkatan pendapatan riil perkapita yang diiringi dengan perubahan dan perbaikan sistem kelembagaan tumbuh dengan perubahan. Oleh karena itu, dalam mengukur perkembangan ekonomi, tidak cukup hanya berbicara pertumbuhan PRDB per kapita saja. Selain itu juga akan dibahas masalah perubahan struktur sosial, sistem kelembagaan, perubahan sikap dan perilaku masyarakat yang juga menjadi elemen esensial dalam pembangunan ekonomi. Sarkar dkk., (2012) mengatakan bahwa pembangunan manusia merupakan salah satu pertimbangan inti suatu tingkat pembangunan suatu negara. Pembangunan manusia jelas tentang memperbesar pilihan orang dengan sumber daya alam bersama (Eren dkk, 2014).

Secara teoritis salah satu faktor yang dapat mempercepat IPM adalah peningkatan pendapatan per kapita. Hasan (2013) menunjukkan bahwa PDB per kapita mempengaruhi tingkat pembangunan. Peningkatan ini akan meningkatkan daya beli masyarakat dan pada akhirnya akan meningkatkan kualitas pendidikan dan kesehatan. Namun demikian, tingginya pertumbuhan sektor di daerah belum tentu mencerminkan pemerataan kemakmuran bagi seluruh masyarakat daerah. Selain itu, laju pertumbuhan ekonomi yang pesat dengan sendirinya tidak akan diikuti dengan peningkatan atau peningkatan distribusi keuntungan bagi seluruh penduduk. Peningkatan kinerja indikator pembangunan manusia dapat mempercepat transformasi negara dari negara berkembang menjadi negara maju.

Indeks Pembangunan Manusia (IPM) adalah suatu indikator yang mengukur bagaimana penduduk dapat mengakses hasil pembangunan dalam memperoleh pendapatan,kesehatan, pendidikan dan sebagainya (Herrero dkk, 2012). Indeks Pembangunan manusia merupakan salah satu indikator untuk mengukur taraf kualitas fisik dan non fisik penduduk. Kualitas fisik tercermin dari angka harapan hidup sedangkan kualitas non fisik melalui lamanya rata-rata penduduk bersekolah dan angka melek huruf. Indeks Pembangunan Manusia (IPM) sebagai salah satu 
indikator kesejahteraan masyarakat ternyata semakin membaik selama dua dekade terkahir, meskipun laju perbaikannya relatif tertinggal dibanding dengan negaranegara tetangga (Wibowo, 2019; Paprotny, 2021)

Tabel 1 PRBB Provinsi Kepulauan Bangka Belitung dan Kepulauan Riau ADH Berlaku 2014-2018.

\begin{tabular}{lccccc}
\hline Provinsi & $\mathbf{2 0 1 4}$ & $\mathbf{2 0 1 5}$ & $\mathbf{2 0 1 6}$ & $\mathbf{2 0 1 7}$ & $\mathbf{2 0 1 8}$ \\
\hline Riau & 679.395 .860 & 652.761 .631 & 681.699 .030 & 704.797 .584 & 755.274 .285 \\
Bangka Belitung & 219.040 .070 & 236.655 .780 & 252.287 .036 & 269.853 .381 & 277.175 .831 \\
\hline
\end{tabular}

Sumber: Data diolah, 2019

Melalui Tabel 1, bisa dilihat lapangan usaha dalam Produk Domestik Regional Bruto (PDRB) di Provinsi Kepulauan Bangka Belitung dan Provinsi Kepulauan Riau atas dasar harga berlaku menurut lapangan usaha 2014-2018 cenderung mengalami peningkatan setiap tahun. PDRB di Provinsi Kepualauan Riau atas dasar harga berlaku menurut lapangan usaha menunjukkan trend yang lebih tinggi dibandingkan dengan Provinsi Kepulauan Bangka Belitung, hal ini dikarenakan Lapangan Usaha terbesar yang menunjang PDRB di Kepulauan Riau yaitu industri pengolahan pada komoditas sektor kelapa sawit. Provinsi Kepulauan Bangka Belitung Mengungguli sektor pertambangan pada komoditas timah sebagai penunjang perekonomian yang tidak dapat diperbaharui sehingga apabila sektor pertambangan mengalami perlambatan ekspor akibat izin usaha yang hanya bisa dilakukan oleh PT.Timah akan berdampak juga terhadap perlambatan PDRB.

PDRB telah mengalami pertumbuhan yang baik namun dampaknya terhadap indikator indeks pembangunan manusia belum sepenuhnya mampu meningkatkan beberapa indikator seperti usia harapan hidup belum efektif (Khodabakhshi, 2011). Indeks pembangunan manusia (IPM) berkaitan positif dengan pertumbuhan ekonomi. Semakin tinggi Indeks Pembangunan Manusia berdampak pada semakin besar pula laju pertumbuhan ekonomi (Novid dan Sumarsono, 2018).

Tabel 2 Data Indeks Pembangunan Manusia (IPM) Provinsi Kepulauan Bangka Belitung dan Kepulauan Riau 2014-2018

\begin{tabular}{llllll}
\hline Provinsi & $\mathbf{2 0 1 4}$ & $\mathbf{2 0 1 5}$ & $\mathbf{2 0 1 6}$ & $\mathbf{2 0 1 7}$ & $\mathbf{2 0 1 8}$ \\
\hline Riau & 70.33 & 70.84 & 71.20 & 71.79 & 72.44 \\
Bangka Belitung & 68.27 & 69.05 & 69.55 & 69.99 & 70.67 \\
\hline
\end{tabular}

Sumber:Data diolah, 2019

Berdasarkan Tabel 2, Indeks Pembangunan Manusia (IPM) di Provinsi Kepulauan Riau dan Kepulauan Bangka Belitung mengalami peningkatan setiap tahun. IPM Provinsi Kepulauan Riau lebih tinggi dibandingkan IPM Provinsi Kepulauan Bangka Belitung. IPM tertinggi di Provinsi Kepulauan Riau pada tahun 2018 sebesar 927,22 dan IPM Provinsi Kepulauan Bangka Belitung tertinggi pada tahun 2018 sebesar 566,00. IPM Provinsi Kepulauan Riau tahun 2018. Hal ini dikarenakan peningkatan pembangunan manusia dari segi pendapatan,kesehatan dan pendidikan masyarakat di Kepulauan Riau dan Kepulauan Bangka Belitung. 
Solfilda dkk., (2015) melihat bahwa daerah yang memiliki IPM di bawah ratarata IPM nasional menunjukkan bahwa variabel rata-rata belanja perkapita, jumlah penduduk, tingkat pengangguran, alokasi anggaran pendidikan dan kesehatan berpengaruh signifikan terhadap IPM. Selain itu, daerah yang memiliki IPM di atas rata-rata nasional menunjukkan bahwa PDRB, belanja rata-rata perkapita, angka beban tanggungan, angka pengangguran, dan anggaran pendidikan berpengaruh terhadap IPM.

\section{METODE}

Jenis penelitian yang digunakan adalah data sekunder karena penelitian yang dilakukan meliputi objek yang bersifat makro dan mudah di dapat. Data tersebut diolah kembali sesuai dengan kebutuhan model yang gunakan. Sumber databerasal dari berbagai sumber, antara lain statistik provinsi terbitan badan pusat statistik, dan jurnal jurnal ilmiah serta literatur-literatur lain yang berkaitan dengan topik peneliti. Penelitian deskriptif kualitatif menggambarkan serta memahami tentang Komparasi Indeks Pembangunan Manusia dan PDRB Di Provinsi Kepulauan.

Data yang digunakan dalam penelitian ini adalah data sekunder yang didapatkan dari pihak-pihak dan publikasi dari Kantor Badan Pusat Statistik Provinsi Kepulauan Bangka Belitung, internet, buku, dan jurnal pada Tahun 2014-2018. Analisis utama penelitian ini adalah analisis statistik deskriptif dan penyajian dalam bentuk tabel dan grafik.

\section{HASIL DAN PEMBAHASAN}

Produk Domestik Regional Bruto (PDRB) menurut Badan Pusat Statistik adalah jumlah nilai tambah oleh seluruh unit usaha dalam suatu negara tertentu, atau merupakan jumlah nilai barang dan jasa akhir yang dihasilkan oleh seluruh unit ekonomi. PDRB atas dasar harga berlaku menggambarkan nilai tambah barang dan jasa yang dihitung menggunakan harga yang berlaku pada setiap tahun, sedangkan PDRB atas harga konstan menunjukkan nilai tambah barang dan jasa tersebut yang duhitung menggunakan harga yang berlaku pada satu tahun tertentu sabagai dasar.

Shah (2016) menyimpulkan bahwa faktor-faktor penentu indeks pembangunan manusia seperti PDB per kapita, angka melek huruf, dan harapan hidup saat lahir. Dalam analisis wilayah negara maju memiliki indeks pembangunan manusia yang lebih tinggi daripada di Asia Selatan dan Afrika Sub-Sahara. Çaglayan-Akay dan Van (2017) menyatakan bahwa dalam jangka pendek variabel PDB mempengaruhi indeks pembangunan manusia. Dalam jangka panjang, variabel yang berpengaruh positif terhadap indeks pembangunan manusia adalah pengeluaran kesehatan, PDB, pengguna internet, persentase tahun sekolah yang diharapkan. Fruin dkk., (2013) menunjukkan bahwa terdapat variasi yang relatif masif dalam laju pertumbuhan pendapatan dalam pembangunan manusia.

Indeks pembangunan manusia (IPM) adalah pengukuran perbandingan dari harapan hidup, melek huruf, pendidikan dan standar hidup untuk semua Negara 
seluruh dunia. Indeks Pembangunan Manusia terdiri dari tiga aspek yaitu: 1.) Indeks Ekonomi (Pendapatan riil per kapita), 2.) Indeks Pendidikan (Angka melek huruf dan lama sekolah), 3.) Indeks Kesehatan (Umur harapan hidup waktu lahir). Indeks pembangunan manusia digunakan untuk mengklasifikasikan apakah sebuah Negara adalah Negara maju, Negara berkembang, atau Negara terbelakang dan juga untuk mengukur pengaruh dari kebijakan ekonomi terhadap kualitas hidup.

\section{PRODUK DOMESTIK REGIONAL BRUTO}

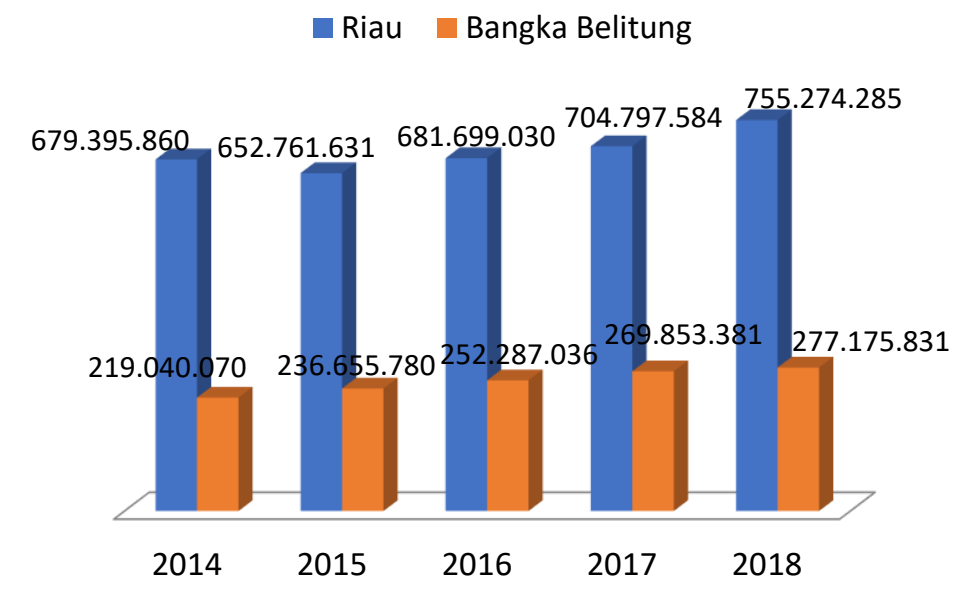

Sumber: Data diolah,2019

Gambar 1. Perkembangan PDRB Kepulauan Bangka Belitung dan Kepulauan Riau

Gambar 1 menunjukkan perkembangan PDRB Provinsi Kepulauan Bangka Belitung dan Kepulauan Riau tahun 2014-2018 mengalami fluktuasi.PDRB Kepulauan Riau pada tahun 2014 lebih tinggi peningkatan dari pada PDRB di Kepulauan Bangka Belitung sebesar 460.355.790. Tahun 2015 Kepulauan Bangka Belitung PDRB mengalami peningkatan dibanding dengan tahun 2014 sebesar 236.655.780 sedangkan Kepulauan Riau PDRB mengalami penurunan dari tahun 2014 sebesar 652.761.631 selain itu Kepulaun Riau masih unggul PDRB dibandingkan dengan Kepulauan Bangka Belitung. Pada tahun 2016 PDRB Kepulauan Riau dan Kepulauan Bangka Belitung mengalami peningkatan dibanding dengan tahun 2015,selain itu juga PDRB Kepulauan Riau masih unggul dibandingkan dengan Provinsi Kepulauan Bangka Belitung. Tahun 2017 PDRB Kepulauan Riau dan Kepulauan Bangka Belitung mengalami peningkatan dibanding dengan tahun 2016, selain itu juga PDRB Kepulauan Riau masih unggul dibandingkan dengan Provinsi Kepulauan Bangka Belitung. pada tahun 2018 PDRB Kepulauan Riau dan Kepulauan Bangka Belitung mengalami peningkatan dibanding dengan tahun 2017, selain itu juga PDRB Kepulauan Riau masih unggul dibandingkan dengan Provinsi Kepulauan Bangka Belitung. . PDRB di Provinsi Kepualauan Riau atas dasar harga berlaku menurut lapangan usaha menunjukkan trend yang lebih tinggi dibandingkan dengan Provinsi Kepulauan Bangka Belitung, hal ini dikarenakan Lapangan Usaha terbesar yang menunjang PDRB di Kepulauan Riau yaitu industri pengolahan pada komoditas sektor kelapa sawit. Provinsi Kepulauan Bangka Belitung Mengungguli sektor pertambangan pada komoditas 
timah sebagai penunjang perekonomian yang tidak dapat diperbaharui sehingga apabila sektor pertambangan mengalami perlambatan ekspor akibat izin usaha yang hanya bisa dilakukan oleh PT.Timah akan berdampak juga terhadap perlambatan PDRB.

Ananta (2013) menunjukkan bahwa PDRB per kapita, berpengaruh terhadap indeks pembangunan manusia. Yuliani dan Saragih (2014) juga menunjukkan bahwa pengangguran, pertumbuhan ekonomi, dan pengeluaran pemerintah berpengaruh terhadap indeks pembangunan manusia di Provinsi Jawa Tengah. Bhakti dkk., (2014) menemukan bahwa faktor-faktor yang mempengaruhi indeks pembangunan manusia di Indonesia adalah PDRB dan anggaran provinsi untuk kesehatan, rasio ketergantungan dan konsumsi rumah tangga untuk pangan. Di sisi lain, anggaran provinsi untuk pendidikan tidak mempengaruhi indeks pembangunan manusia. Pertumbuhan ekonomi, distribusi pendapatan, pengendalian populasi, pengentasan kemiskinan, dan peningkatan layanan kesehatan dan pendidikan sangat penting untuk meningkatkan indeks pembangunan manusia. Bintang dkk., (2015) menunjukkan bahwa faktor-faktor yang mempengaruhi indeks pembangunan di negara OKI adalah anggaran pendidikan, tingkat pendapatan per kapita, dan indeks Gini. Di sisi lain, anggaran kesehatan, dan jumlah penduduk tidak mempengaruhi indeks pembangunan manusia di negara-negara OKI.

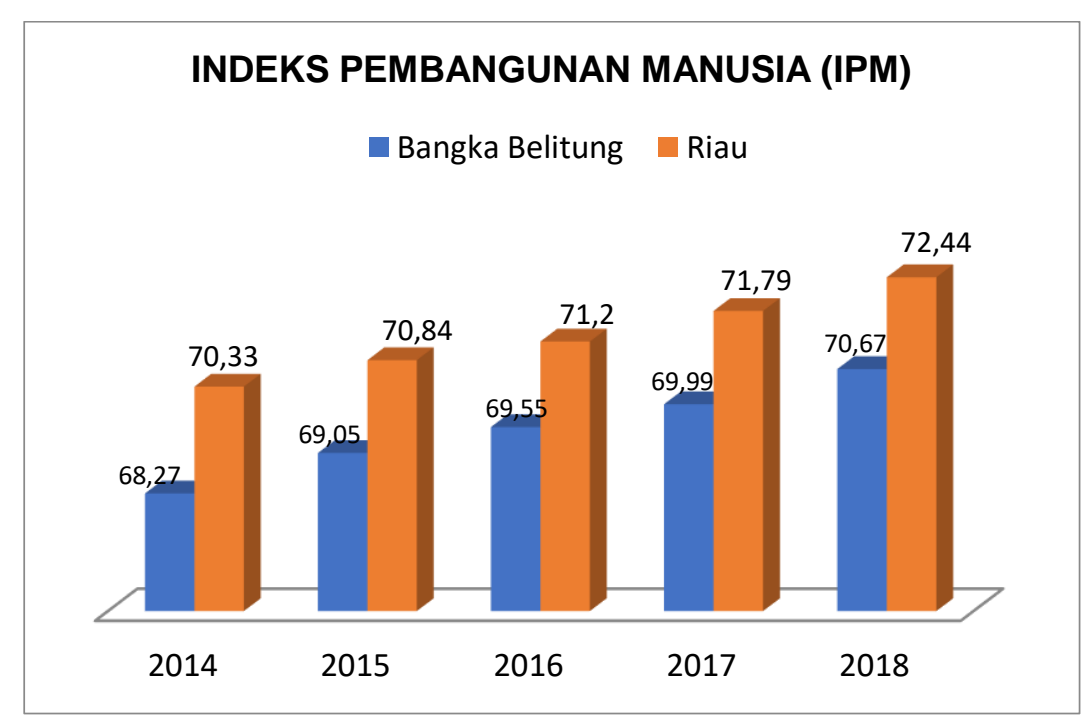

Sumber: Data diolah, 2019

Gambar 2. Perkembangan IPM Kepulauan Bangka Belitung dan Kepulauan Riau

Pada Gambar 2 terlihat bahwa telah terjadi peningkatan IPM di Provinsi Kepulauan Bangka Belitung dan Provinsi Kepulauan Riau setiap tahunnya. Perkembangan IPM menunjukkan peningkatan pencapaian IPM seiring dengan membaiknya perekonomian negara. IPM Kepulauan Riau pada tahun 2014 lebih tinggi peningkatan dari pada IPM di Kepulauan Bangka Belitung sebesar 68,27. Tahun 2015 IPM Kepulauan Bangka Belitung mengalami peningkatan dibanding dengan tahun 2014 sebesar 69,05. Sedangkan IPM Kepulauan Riau mengalami peningkatan tahun 2014 sebesar 70,33. selain itu,IPM Kepulauan Riau masih unggul dibandingkan dengan Kepulauan Bangka Belitung. Pada tahun 2016 IPM Kepulauan Riau dan Kepulauan Bangka Belitung mengalami peningkatan dibanding 
dengan tahun 2015, selain itu juga IPM Kepulauan Riau masih unggul dibandingkan dengan Provinsi Kepulauan Bangka Belitung. Tahun 2017 IPM Kepulauan Riau dan Kepulauan Bangka Belitung mengalami peningkatan. Di Provinsi Kepulauan Riau besarnya nilai pencapaian yang telah dicapai dalam meningkatkan IPM pada akhir tahun 2018 yaitu sebesar 72,44 sedangkan IPM di Provinsi Bangka Belitung pada akhir tahun 2018 yaitu sebesar 70,67. Hal ini dikarenakan peningkatan pembangunan manusia dari segi pendapatan,kesehatan dan pendidikan masyarakat di Kepulauan Riau dan Kepulauan Bangka Belitung.

Dianaputra dan Aswitari (2017) menemukan bahwa pembiayaan pemerintah di bidang pendidikan dan kesehatan berpengaruh terhadap indeks kualitas manusia. Lebih lanjut, pembiayaan pemerintah di bidang pendidikan dan kesehatan berpengaruh tidak langsung terhadap pertumbuhan ekonomi melalui indeks pembangunan manusia. Setiawan dan Hakim (2013) menemukan PDB dan pajak penghasilan baik dalam jangka pendek maupun jangka panjang terhadap HDI. Selain itu, hasil penelitian juga menemukan bahwa krisis ekonomi tahun 2008 berdampak pada IPM. Krisis 1997 dan desentralisasi pemerintah tidak mempengaruhi IPM. Singariya (2014) menyarankan perluasan pemberdayaan perempuan, dan fasilitas rumah tangga penting untuk meningkatkan nilai IPM. Negara-negara yang memiliki nilai IPM tinggi dapat berkonsentrasi pada keempat faktor penentu (harapan hidup saat lahir, tahun sekolah yang diharapkan, tingkat partisipasi tenaga kerja, dan PDB per kapita) dan merancang kebijakan mereka. Bangun (2016) juga menunjukkan bahwa partisipasi ekonomi perempuan masih jauh di bawah laki-laki. Pemerintah juga harus memprioritaskan program diskriminasi ini.

\section{KESIMPULAN}

Berdasarkan data yang telah dianalisis dapat disimpulkan bahwa komparasi indeks pembangunan manusia dan produk domestik regional bruto mengalami peningkatan. Kondisi IPM di Provinsi Kepulauan Bangka Belitung dan Kepulauan Riau cenderung mengalami peningkatan setiap tahunnya dengan rata-rata IPM tertinggi selama periode 2014-2018. Sedangkan Kondisi PDRB di Provinsi Kepulauan Bangka Belitung dan Kepulauan Riau juga cenderung mengalami peningkatan setiap tahunnya dengan rata-rata IPM tertinggi selama periode 20142018.

Perlu menjaga pertumbuhan ekonomi yang stabil agar IPM di kedua provinsi terus meningkat. Temuan ini memperlihatkan adanya kenderuangan yang sama atara PDRB dan IPM, maka belanja pemerintah harus diarahkan untuk mencapai target pertumbuhan dan juga peningkatan IPM.

\section{DAFTAR PUSTAKA}

1) Aitken, A. (2019). Measuring welfare beyond GDP. National Institute Economic Review, 249 (August), R3-R16. doi: https://doi.org/10.1177/002795011924900110 
2) Ananta, P. (2013). Determinants of Human Development in Lampung Province. Jurnal Ekonomi Pembangunan, 2(3), 243-257.

3) Bangun, W. (2016). Efforts of Indonesia to Improve of Gender Equality on ASEAN Economic Community (AEC). Review of Integrative Business and Economics Research, 5(2), 167-174.

4) Bhakti, N.A., Istiqomah, dan Suprapto. (2014). Analisis Faktor-faktor yang Mempengaruhi Indeks Pembangunan Manusia di Indonesia Periode 2008-2012. Ekuitas: Jurnal Ekonomi dan Keuangan, 18(4), 452-469. https://doi.org/10.24034/j25485024.y2014.v18.i4.97

5) Bintang, M., Ismail, N., dan Indra. (2015). Determinan Indeks Pembangunan Manusia: Analisa Pendekatan Maqasid Syariah Al-Ghazali: Studi Kasus: Negara-negara OKI. Eksyar, 2 (2), 512-534. https://ejournal.staimtulungagung.ac.id/index.php/eksyar/article/view/215

6) Çaglayan-Akay, E., dan Van, M.H. (2017). Determinant of the Levels of Development Based on the Human Development Index: Bayesian Ordered Probit Model. International Journal of Economics and Financial Issues, 7(5), 425-431. https://www.econjournals.com/index.php/ijefi/article/view/5271

7) Dianaputra, I.G.K.A., dan Aswitari, L.P. (2017). Pengaruh Pembiayaan Pemerintah di Sektor Pendidikan dan Kesehatan Terhadap Indeks Kualitas Manusia Serta Pertumbuhan Ekonomi Pada Kabupaten/Kota Provinsi Bali Tahun 2011-2015. E-Jurnal Ekonomi Pembangunan Universitas Udayana, 6(3): 115-146. https://ojs.unud.ac.id/index.php/eep/article/view/27890

8) Eren, M., Çelik, A.K., dan Kubat, A. (2014). Determinantf of the Level of Development Based on the Human Development Index: A Comparison of Regression Models for Limited Dependent Variables. Review of European Studies, 6(1): 10-23. doi: https://doi.org/10.5539/res.v6n1p10

9) Fruin, M., Peneva, D., \& Ram, R. (2013). Income Elasticity of Human Development in ASEAN Countries. The Empirical Econometrics and Quantitative Economics Letters, 2(4): 13-20. https://ideas.repec.org/a/chi/journl/v2y2013i4p13-20.html

10) Hasan, Z. (2013). Determinants of Human Resource Development: An Empirical Analysis. International Journal of Economics, Management, and Accounting, 8 (2). Diambil dari from http://journals.iium.edu.my/enmjournal/index.php/enmj/article/view/62

11) Herrero, C., Martínez, R., Villar, A. (2012). A newer human development index. Journal of Human Development and Capabilities, 13(2), 247-268. doi: https://doi.org/10.1080/19452829.2011.645027

12) Khodabakhshi, A. (2011). Relationship between GDP and Human Development Indices in India. International Journal of Trade, Economics and Finance, 2(3), 251-253. doi: https://doi.org/10.2139/ssrn.1867887

13) Novid, A. dan Sumarsono, H. (2018). Human development index, capital expenditure, fiscal desentralization to economic growth and income inequality in East Java Indonesia. Quantitative Economics Research 1(2), 108-118. Diambil dari http://journal2.um.ac.id/index.php/qer/article/view/3565/3177

14) Paprotny, D. (2021). Convergence Between Developed and Developing Countries: A Centennial Perspective. Social Indicators Research 153, 193-225. Doi: https://doi.org/10.1007/s11205-020-02488-4

15) Sarkar, Md.S.K., Sadeka, S., dan Sikdar, Md.M.H. (2012). Human Development Scenario of Malaysia: ASEAN and Global Perspective. Asian Journal of Applied Science and Engineering, 1(1): 23-34. https://www.journals.abc.us.org/index.php/ajase/article/view/1.3.12

16) Setiawan, M.B., dan Hakim, A. (2013). Indeks Pembangunan Manusia Indonesia. Jurnal Economia, 9(1), 18-26. 
17) Shah, S. (2016). Determinant of Huan Development Index: A Cross-Country Empirical Analysis. Munich Personal RePEc Archive (MRPA) Paper No. 73759. Diambil dari https://mpra.ub.uni-muenchen.de/73759/1/MPRA paper 73759.pdf

18) Singariya, M.R. (2014). Socioeconomic Determinantf of Human Development Index in India. Management and Administrative Sciences Review, 3(1), 69-84.

19) Solfida, E., Hermiyanti, P., danHamzah, M.Z. (2015). Determinant Variable Analysis of Human Development Index in Indonesia: Case for High and Low Index at Period 20042013. International Journal of Sustainable Development, 8(9), 11-27. https://papers.ssrn.com/sol3/papers.cfm?abstract id=2695465

20) Syari, D.D., Syamsurijal, A.K, Robiani, B. (2017). The effect of fiscal decentralization to gross domestic regional product of district/city in South Sumatra Province. Sriwijaya International Journal of Dynamic Economics and Business 1(2), 181-202. https://doi.org/10.29259/sijdeb.v1i2.181-202

21) Wibowo, M.G. (2019). Human capital relation with welfare in Indonesia and Asean countries. Economics Development Analysis Journal 8(1), 81-93. Diambil dari https://journal.unnes.ac.id/sju/index.php/edaj/article/view/28730/13060

22) Yuliani, T., dan Saragih, N. (2014). Determinan Pembangunan Manusia di Kabupaten/Kota di Provinsi Jawa Tengah. JEJAK: Journal of Economics and Policy,7(1), 60-72. https://journal.unnes.ac.id/nju/index.php/jejak/article/view/3843 